[Tinjauan Buku]

\title{
Kelas Sosial sebagai Tantangan Pemuda dalam Peluang Kerja
}

Oktafia Kusuma Sari dan Gigich Ilmy Al Bonadi

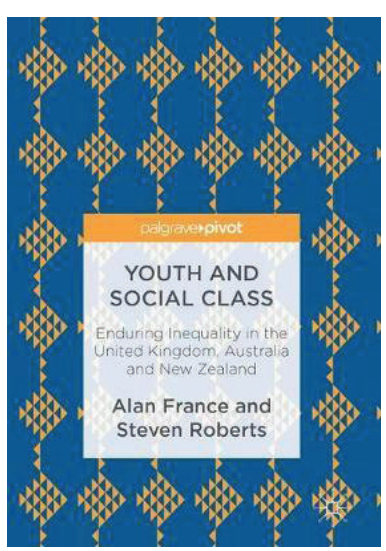

Judul Asli

Penulis

Penerbit

Tahun

ISBN
Youth And Social Class: Enduring Inequality in the United Kingdom, Australia and New Zealand

Alan France dan Steven Roberts

Macmillan Publishers Ltd.

2017

$978-1-137-57829-7$
Cepatnya perubahan sosial yang terjadi telah mengesampingkan kelas sosial dalam studi kepemudaan. Buku ini sangat menarik untuk disimak karena memberikan perspektif baru tentang kelas sosial dan pemuda. Secara keseluruhan buku ini membuktikan bahwa kelas sosial dalam disiplin studi kepemudaan masih sangat relevan. Hal tersebut ditunjukan dari bagaimana kelas sosial direproduksi oleh kaum muda di masa new modern di tiga negara yaitu United Kingdom, Australia, dan Selandia Baru. Di awal, buku ini menjelaskan tentang kondisi pemuda pada masa transisi dari sekolah ke dunia kerja, oleh karena itu buku ini sangat terfokus pada tataran pemuda dalam pendidikan akhir seperti perguruan tinggi dan pelatihan-pelatihan yang bermuara pada proses pencarian pekerjaan. Buku ini mencoba menjelaskan perubahan model pemuda yaitu "school to work" kemudian disusul dengan pertanyaan dalam buku ini mengenai apakah dengan model transisi tersebut menyediakan sarana untuk peningkatan sosial, pribadi, hingga mobilitas sosial kaum pemuda atau bisa jadi adanya transisi model ini berfungsi untuk mempertahankan "status quo" yang meneguhkan ketidaksetaraan melalui reproduksi sosial yang selama ini dilakukan.
Alan France dan Steven Roberts juga menggambarkan bagaimana "socio-cultural incongruity" yang diungkapkan oleh Devlin (2013) adalah suatu kebutuhan. Namun temuan seperti itu tidak meng arah dan memberikan solusi yang lebih efektif akan kondisi ketidaksetaraan kelas pasca-pendidikan yang dialami oleh pemuda. Hal itu bisa terjadi karena terdapat suatu hal yang terlupakan yaitu "education is a social field". Buku ini memandang pendidikan adalah sebuah "social field" yang pada dasarnya akan selalu menjadi tempat perjuangan atas ketidaksetaraan. Jika "social field" ini diabaikan dalam pendidikan maka kaum muda juga memproduksi ketidaksetaraan itu sendiri. Hal itu bisa terjadi karena ketika tidak ada cara pandang "education is a social field" maka mereka akan tunduk pada perebutan kekuasaan memproduksi ulang status quo yang sudah ada. Kondisi tersebut dapat dikatakan sebagai "business of social reproduction" yang menawarkan prospek mobilitas sosial tetapi mempertahankan status quo seperti pendapat Devlin (2003) bahwasannya memproduksi ulang status quo yang sudah ada. Kondisi tersebut dapat dikatakan sebagai "business of social reproduction" yang menawarkan prospek mobilitas sosial 
tetapi mempertahankan status quo seperti pendapat Devlin (2003) bahwasannya "Access without a reasonable chance of success is an empty phrase". Berdasarkan paparan di atas, sebenarnya buku ini ingin mempertegas bahwa kelas sosial harus tetap berada di dalam studi dan diskusi politik.

Bab selanjutnya menjelaskan secara lebih dalam mengenai pekerjaan secara signifikan berpengaruh terhadap kelas dalam sosiologi pemuda. Menurut Pollock, kelas sosial penting dalam menganalisis kendala struktural untuk mengetahui alasan dan tujuan pemuda pada masa transisi school to work. Fakta bahwa ternyata angkatan kerja muda menjadi sasaran dari ketidakadilan karena pemuda lebih cenderung mudah dipekerjakan dengan gaji yang lebih rendah serta jam kerja yang berlebihan dengan dasar untuk mencari pengalaman. France dan Roberts menyadari bahwa harus kembali melihat tren yang sedang terjadi di generasi muda kontemporer. Era industri baru memberikan dampak kepada meningkatnya bentuk pekerjaan yang tidak standar dan menurunkan upah walaupun memang di sisi lain meningkatkan pekerjaan paruh waktu, zero contract dan berpengaruh langsung terhadap menurunnya upah relatif pemuda di negara maju seperti Selandia Baru, Inggris, dan Australia.

Perubahan pasar kerja pasca perang dunia kedua mungkin tidak memunculkan masalah akan tetapi dalam tren jangka panjang, risiko pasar semakin dibebankan ke pekerja dan jauh dari perusahaan. Tren yang dijelaskan oleh penulis bahwa pada tahun 2010 juga menunjukkan adanya polarisasi pekerjaan yang disebabkan oleh tergesernya pekerja dengan skill manual oleh mesin. Dalam buku ini, Gallie dan Paugam menyatakan bahwa pekerjaan tidak menjamin integrasi sosial, dalam jangka panjang pekerjaan berkualitas rendah cenderung membuat banyak orang sangat rentan kehilangan pekerjaan dan akhirnya memarjinalisasi pasar tenaga kerja.

Argumen dalam buku ini mengakui bahwa dalam menganalisis kelas, perubahan ekonomi dan sosial tidak menjadi penghambat dalam menganalisis kondisi kontemporer pemuda. Sebelum menganalisis lebih jauh tentang tujuan kerja dan pengalaman kerja setelah lulus dari Universitas, buku ini terlebih dahulu menjelaskan tentang perubahan besar pada pekerjaan yang dilakukan oleh pelajar. Angka partisipasi di tingkat universitas yang tinggi menjadikan banyak tekanan bagi mahasiswa yang berlatar belakang ekonomi rendah sehingga melakukan kerja paruh waktu. Buku ini juga berhasil menjelaskan bahwa institusi pendidikan tinggi, terutama Universitas dan sektor kejuruan, sangat memengaruhi pola pekerjaan pemuda dan kelas sosial. Dikatakan bahwa pemuda golongan bawah akan cenderung mengikuti kelas kejuruan dan nantinya akan menjadi kelas pekerja. Di sisi lain, pendapatan tetap orang tua juga berpengaruh terhadap pendapatan pemuda setelah lulus dari Universitas. Bisa ditarik kesimpulan bahwa pemuda dengan kemampuan ekonomi rendah memiliki peluang besar dalam melakukan kerja part-time selama menempuh dan berpengaruh terhadap kualitas gelar lulusan yang diperoleh. Di Inggris sendiri menunjukkan bahwa tingkat pendidikan yang dicapai tidak bisa menjamin pekerjaan yang lebih tinggi. Bahkan ketika pemuda bisa mendapatkan gelar dari universitas lokal mereka masih sangat mungkin untuk mendapat pekerjaan dengan berpenghasilan rendah, pekerjaan sementara, dan pengangguran.

Penjelasan tentang kelas juga diperoleh tidak hanya pada kondisi bekerja setelah lulus dari Universitas, tetapi dalam proses magang pun terdapat pemisahan kelas dimana untuk mendapatkan pekerjaan pemuda harus memiliki setidaknya lebih dari satu kali pengalaman magang. Dilema yang harus dihadapi adalah bahwa magang tidak memberikan gaji cukup besar sehingga pemuda dengan kelas menengah bisa magang dalam waktu yang lebih panjang tanpa ada kesulitan ekonomi, sedangkan kelas bawah akan sulit mengakses karena keterbatasan ekonomi. Selain berakar dari Universitas, hubungan kelas dan pekerjaan pemuda di masa depan dipengaruhi juga oleh pemberi kerja, dimana 40\% perusahaan di Australia lebih mengutamakan untuk merekrut lulusan dari Universitas ternama.

Pada bab selanjutnya, dijelaskan bahwa kelas sosial cenderung termarjinalkan bahkan $\mathrm{ku}^{-}$ rang diberikan perhatian dalam menganalisis studi kepemudaan. Korelasi antara kelas sosial dengan studi kepemudaan dapat ditinjau dari pendekatan Bourdieu. Argumen penulis diperkuat melalui kajian historis bagaimana diskusi perihal kelas sosial yang 
selalu diasumsikan dengan gender dan ras telah termarjinalkan pasca-strukturalisme sehingga tidak hadir dalam studi kepemudaan. Di samping itu diskusi perihal gender dan ras juga terlalu difokuskan dengan perkembangan studi identitas sehingga aspek kelas sosial dilupakan. Padahal, menurut penulis, aspek kelas sosial perlu dimasukkan dalam diskusi gender dan ras karena akan menciptakan pemahaman tentang bagaimana suatu golongan seperti kehidupan wanita muda dari kelompok etnis yang berbeda sedang dikonstruksi. Hal tersebut dijelaskan lebih jauh lagi oleh penulis melalui sejarah imigrasi di Inggris dan kolonialisme di Australia bahkan juga di Selandia Baru.

Pada bab terakhir penulis lebih mempertegas bahwa studi kepemudaan dan kelas sosial perlu dianalis melalui kacamata Bourdieusian. Hal tersebut dirasa penting karena studi kepemudaan perlu menjawab mitos masyarakat tanpa kelas, dari situlah Bourdieusian bekerja untuk menganalisis permasalahan yang ada. Teori Bourdieu menurut penulis juga mampu menjelaskan korelasi antara studi kepemudaan dengan kelas sosial di tengah-tengah perubahan sosial yang dinamis. Adanya perubahan ini perlu menjadi variabel pertimbangan karena mempunyai pengaruh terhadap kehidupan kaum muda. Hal ini menjadi landasan penulis akan perlunya pendekatan Bourdieu untuk menganalisis kasus-kasus di negara lain. Cara kerja pendekatan Bourdieu dapat ditinjau dari bagaimana pemuda mengenali peran penting aspek sosial mengenai bagaimana kelas sosial beroperasi dengan cara sangat beragam dan rumit sehingga berpengaruh dalam kehidupan pemuda di era kontemporer.

Argumen dalam buku ini dapat dikontekstualisasikan dengan kondisi di Indonesia terkait pemuda dan bonus demografi pada tahun 20302045. Menurut Suyatna dan Nurhasanah (2017), kondisi ini adalah bonus demografi Indonesia karena usia produktif lebih banyak dari usia non-produktif. Adanya bonus demografi ini diperkirakan mampu mendongkrak Indonesia karena usia produktif lebih banyak dari usia non-produktif. Adanya bonus demografi diperkirakan mampu mendongkrak pendapatan hingga 30.000 USD per tahun. Namun, untuk memanfaatkannya maka perlu muncul aktor muda yang bergerak dalam bidang ekonomi sebagai agen sociopreneur. Sociopreneurship diharapkan dapat memecahkan masalah sosial di Indonesia, dengan cara menempatkan masyarakat sebagai aktor mitra dan bersama-sama menciptakan bisnis yang berorientasi pada peningkatan kesejahteraan, bukan profit belaka. Namun tidak semua pemuda dapat menjadi sociopreneur. Kelas sosial masih menjadi elemen penting dalam menentukan titik awal berjalannya sekaligus kesuksesan bisnis sosial.

Secara keseluruhan, buku ini cenderung fokus untuk menggambarkan hubungan antara studi kepemudaan dan kelas sosial dalam ranah pekerjaan di tiga negara yaitu Inggis, Selandia Baru, dan Australia. Penjelasan dalam penelitian ini digambarkan melalui studi kasus terkini di tiga negara tersebut. Namun, penulis tidak memberikan solusi atas dampak dari adanya hubungan kepemudaan dan kelas sosial dan berhenti pada tataran penjelasan saja. Di sisi lain, pemilihan kasus di tiga negara sangat relevan dengan perkembangan teori kelas dalam sosiologi. Relevansi tersebut dapat dilihat ketika teori kelas mendapatkan ruangnya kembali setelah termarjinalkan dari studi kepemudaan.

Buku ini menyadarkan pentingnya kajian lebih lanjut mengenai studi kepemudaan yang dibingkai dalam teori kelas. Disadari atau tidak hubungan pekerjaan pemuda pascalulus dari Universitas dan pasar tenaga kerja karena pertumbuhan ekonomi dan perubahan sosial semakin terlihat secara global. Pemuda di era new modern berada dalam tingkat persaingan yang tinggi untuk sukses dan hal kesuksesan tersebut tidak bisa lepas dari modal keluarga dan modal individu (ekonomi, sosial, dan budaya). Modal individu tergantung pada posisi kelas sosialnya serta dalam prosesnya akumulasi modal terkait dengan strategi pemuda dalam mengumpulkan bentuk modal baru. Dengan kata lain, kelas sosial masih menjadi faktor yang relevan dalam proses transisi pemuda menuju dunia kerja.

\section{DAFTAR PUSTAKA}

Suyatna,Hempri,dan Nurhasanah, Yanti. 2017. "Sociopreneurship Sebagai Tren Karir Anak Muda”. Jurnal Studi Pemuda Vol. 6 No. 1 2017. 